\title{
Aleksandra Litawa
}

https://orcid.org/0000-0003-2004-8450

Uniwersytet Pedagogiczny w Krakowie

\section{Realizowanie harmonijnej pasji jako działanie autokreacyjne}

\author{
The engagement in harmonious passion \\ as self-creation
}

\begin{abstract}
Streszczenie. Poszukiwanie drogi spełnienia u każdej jednostki przebiega inaczej i dotyczy różnych aspektów życia. Jedną ze ścieżek realizacji własnego potencjału rozwojowego może być harmonijna pasja. Podjęte w tekście analizy miały na celu rozpoznanie wspólnych dla pasji i autokreacji kategorii oraz uzasadnienie tezy, że urzeczywistnianie pasji można postrzegać jako działanie autokreacyjne. Dokonano charakterystyki pasji i autokreacji, a następnie wyróżniono wspólne dla nich kategorie, tj. rozwój, wartości, twórczość oraz transgresję. Przeprowadzone analizy dały podstawę do sformułowania dwóch wniosków. Po pierwsze, pasja może stanowić jedną z dróg autokreacji. Po drugie, pasja może dać początek autokreacyjnym dążeniom podmiotu. Rozważania zakończono konstatacją, że proces urzeczywistniania harmonijnej pasji, w perspektywie samorealizacji jednostki, można określić mianem działania autokreacyjnego.
\end{abstract}

Słowa kluczowe: pasja, autokreacja, samorealizacja, samotranscendencja

Summary. The search for the way of fulfilment in each individual is different and concerns different aspects of life. A passion may be one of the paths to realizing one's development potential. The analyses undertaken in the text were aimed at identifying categories common to passion and self-creation and justifying the thesis that the realization of passion can be perceived as self-creation activity. Passion and self-creation were characterised, and then the categories common to them were distinguished; i.e. development, values, creativity, and transgression. Based on the analyses conducted, two conclusions were formulated. The first is 
that passion can be one of the ways of self-creation. The second conclusion shows that passion can give rise to the subject's self-creative aspirations. The considerations ended with the conclusion that the process of realizing a harmonious passion, in the perspective of an individual's self-realization, can be described as a self-creative activity.

Keywords: passion, self-creation, self-realization, self-transcendence

Chcesz wiedzieć kim jesteś? Nie pytaj. Działaj. Działanie cię określi i ustali. $Z$ działania twojego się dowiesz. Ale działać musisz jako „ja”, jako jednostka, bo tylko własnych potrzeb, skłonności, namiętności, konieczności możesz być pewny. Resztaczyż to nie recytowanie, wypełnianie schematów, tandeta, kicz? [...] Być kimś, to dowiadywać się nieustannie kim się jest, a niewiedzieć $\mathrm{z}$ góry.

(Gombrowicz 1986, s. 162)

\section{Wprowadzenie}

Człowiek nie istnieje po to, by być, ale po to, by się stawać (Frankl 1998, s. 47). Poszukiwanie drogi spełnienia, urzeczywistnianie potencjalnej, lepszej wizji siebie u każdej jednostki przebiega inaczej i dotyczy różnych aspektów życia. Zwykle jednak wiąże się z tym rodzajem działalności, który postrzega ona jako ważny i wartościowy z punktu widzenia jej funkcjonowania osobowego i społecznego. Jedną ze ścieżek realizacji własnego potencjału rozwojowego może być pasja.

Pasja stanowi ważną część tożsamości człowieka, jest czymś, co go w znacznym stopniu definiuje. Osoba posiadająca pasję nie mówi o sobie: „interesuję się malarstwem” czy „pasjonuję się sportem”, ale: „jestem artystą", ,jestem sportowcem” (Litawa 2019). Istnieją dwa rodzaje pasji: harmonijna i obsesyjna. Aktywność podejmowana w ramach harmonijnej pasji, mimo że wypełnia znaczną część czasu w życiu człowieka, nie przytłacza go, ale współgra $z$ innymi aspektami jego życia. Jednostka w pełni kontroluje swoją działalność, która prowadzi ją do uzyskania korzystnych efektów zarówno podczas aktywności (pozytywne emocje i nastawienie, koncentracja, uskrzydlenie), jak i po jej zakończeniu (satysfakcja, pozytywne nastawienie do świata) (Vallerand 2012). Obsesyjna pasja natomiast wy- 
zwala w jednostce stan bliski uzależnieniu. W tym przypadku można odnieść wrażenie, że to pasja kontroluje człowieka, a nie na odwrót. Działalności zorientowanej na realizację tego rodzaju pasji towarzyszą poczucie winy lub wstydu (jak w przypadku hazardu), jak również zachowania zagrażające życiu czy zdrowiu (np. tancerz, który mimo kontuzji nie przestaje trenować). Obsesyjna pasja prowadzi do negatywnych konsekwencji (wewnętrzne skonfliktowanie jednostki, negatywne myśli i emocje, obniżenie samopoczucia) (Philippe i in. 2009; Stenseng i in. 2011).

Rozważania zawarte w prezentowanym tekście odnoszą się do harmonijnej pasji rozumianej jako istotny obszar aktywności życiowej, w którym człowiek kreuje własne „ja”. Celem podjętych analiz było rozpoznanie wspólnych dla pasji i autokreacji kategorii oraz uzasadnienie tezy, że pasję można postrzegać jako działanie autokreacyjne.

\section{Istota pasji}

Pasja odnoszona do ludzkiego doświadczenia jest zjawiskiem indywidualnym i wysoce subiektywnym, a jej podstawową cechą charakterystyczną jest unikatowość. Stąd każda próba nadania jej sztywnych ram definicji z góry skazana jest na niepowodzenie. Praktyczny słownik współczesnej polszczyzny podaje, że pasja to szczególne, bardzo silne upodobanie, zamiłowanie do czegoś, jak również przedmiot tej namiętności (Zgółkowa 2000, s. 12). Pasją jest to, w imię czego człowiek jest gotów do poświęceń i do pokonywania trudności. Maria Czerepaniak-Walczak, wskazując na grecki źródłosłów pasji (pathos - cierpienie, erotas - miłość), określa ją jako silną emocję (pozytywną lub negatywną) rządzącą zachowaniem człowieka. Zdaniem autorki, pasja to namiętność, która wyzwala aktywność zorientowaną na osiągnięcie tego, co z punktu widzenia danej osoby jest wartościowe. „Jako siła sprawcza ludzkiej aktywności, chęci i radości płynącej z działania, pozwala znajdować i nadawać sens życiu, dodawać odwagi przekraczania siebie" (Czerepaniak-Walczak 2015, s. 54). W takim ujęciu pasja stanowi istotny czynnik zmiany jednostki i jej świata życia.

Pasja jest czymś osobistym, unikalnym i niepowtarzalnym, a przez to niejednoznacznym. Z zewnątrz może przybierać formę bardziej lub mniej spektakularną, co z punktu widzenia zaangażowanej w realizację pasji jednostki nie ma żadnego znaczenia. Bez względu na to, czy pasją człowieka są sporty ekstremalne, czy kolekcjonerstwo znaczków pocztowych, 
jest ona dla niego źródłem równie ważnych przeżyć, doznań i uczuć. Bo sama w sobie pasja nie jest ważna, to człowiek nadaje jej znaczenie. Ten specyficzny rodzaj relacji bardzo obrazowo przedstawia Maria Dudzikowa (2015) w eseju dotyczącym jej pasji do książek. Lektura tekstu uzmysławia czytelnikowi, jak znacząca różnica istnieje pomiędzy stanami: „lubić książki” a „pasjonować się książkami”...

Za realizacją pasji kryje się coś więcej niż tylko sposób na przyjemne spędzenie czasu wolnego. Pasja jest „najwyższą formą zaangażowania, kreatywności i aktywnego tworzenia swojej biografii" (Dudzikowa, Nowak 2015, s. 7). Daje poczucie autentyczności i wolności, wprowadza jednostkę w stan uskrzydlenia, wyzwolenia. Pozwala człowiekowi znaleźć się w sytuacji, którą Ken Robinson i Lou Aronica (2012) nazywają „byciem w Żywiole” lub „byciem uskrzydlonym”, aMihály Csíkszentmihályi (1996) „doświadczeniem przepływu” lub „optymalnym doświadczeniem”. Urzeczywistniając swoją pasję, jednostka oddaje się czynnościom, które kocha i postrzega jako fascynujące. Doświadczenia towarzyszące jej w chwili obcowania z obiektem pasji, działania, które podejmuje, wypełniają ją energią, dodają sił, inspirują do dalszych poszukiwań i rozwoju (Litawa 2019). Realizacji pasji towarzyszy głębokie przekonanie jednostki o sensowności i ważności podejmowanych czynów.

\section{Trzy drogi tworzenia własnego ,ja"}

W rozważaniach nad człowiekiem i jego człowieczeństwem autokreacja wydaje się pojęciem kluczowym. To zarazem jedno z tych określeń, które często rozumie się i stosuje intuicyjnie. Wynika to $\mathrm{z}$ faktu, że o autokreacji nie sposób mówić w oderwaniu od terminów jej pokrewnych, które przez jednych badaczy traktowane są synonimicznie, przez pozostałych zamiennie. Autokreację cechuje wielozakresowość i konfiguratywność z innymi kategoriami, takimi jak samorealizacja, samorozwój czy samokształtowanie (Górniok-Naglik 2014, s. 80). Eksploracja sposobów rozumienia autokreacji prezentowanych przez autorów wywodzących się z różnych dyscyplin naukowych prowadzi do konstatacji, że najczęściej bywa ona utożsamiana z samorealizacją lub samotranscendencją (Wąsiński 2018, s. 351).

Realizowanie siebie polega na stawaniu się tym, kim chce się być, na dążeniu do lepszej wersji siebie. Odkrywając i aktualizując swoje potencjalne zdolności, jednostka dąży do potwierdzenia własnej wartości, do roz- 
woju swojej osobowości, do przezwyciężenia ograniczeń w pełnym byciu sobą (Matwijów 1994, s. 112). Samorealizujący się człowiek zorientowany jest ku sobie, ku swojemu wewnętrznemu światu. W wyniku podejmowanej autorefleksji dąży do samopoznania (kim i jakim jestem?), samookreślenia (kim i jakim chcę być?) oraz samorozumienia (kim i jakim warto być?) (Wąsiński 2018, s. 350). Autorefleksja pojawiająca się u niego w sytuacjach problemowych prowadzi do ponownego odkrywania przed samym sobą rzeczywistego obrazu siebie, pełniejszego zrozumienia źródeł motywacji własnych wyborów i czynów, uświadomienia stopnia internalizacji wyznawanych wartości, otwarcia się na innych ludzi i określenia jakości nawiązywanych z nimi kontaktów (poziom samowiedzy); do „pogodzenia" się z samym sobą, uznania tego, jakim się jest pod względem zarówno własnych słabości, jak i walorów, z których płynie wola działania ukierunkowanego na samodoskonalenie się (poziom samoakceptacji); do zaktualizowania życzeniowej wizji siebie (poziom autokreacji) (Wąsiński 2011, s. 323-324). Jednostka definiuje bieżący obraz siebie, określa poziom samoakceptacji, a następnie wizję siebie idealnej, ku której decyduje się dążyć. „Próba wyjścia od Ja realnego i urzeczywistnienia Ja potencjalnego inicjuje złożony proces projektowania własnej drogi życiowej, która jest de facto kreowaniem pozytywnej przemiany wewnętrznej zgodnie $z$ pewną wyidealizowaną, lecz możliwą do urzeczywistnienia wizją siebie" (Wąsiński 2011, s. 323).

Samorealizacja związana jest z transcendencją - człowiek dąży do tego, by przekraczać to, czym obdarzyła go natura. W efekcie wysiłku włożonego w pracę nad samym sobą osiąga poczucie sensu życia, poczucie spełnienia swojej istotowości, zyskuje uznanie dla samego siebie (Górniewicz 2001, s. 55). Tym samym staje się gotowy, by tworzyć nowe związki ze światem, by wiedzę oraz umiejętności uzyskane w toku samorealizacji zacząć wykorzystywać dla dobra innych.

W pełni urzeczywistniona samorealizacja kieruje człowieka w stronę samotranscendencji, która umożliwia mu wyjście poza samego siebie. Orientacja ku sobie ustępuje miejsca orientacji ku światu: ku innym ludziom i sensom, które można wypełnić (Frankl 2018, s. 47). Zdaniem Viktora Frankla, samotranscendencja stanowi istotę egzystencji. Być człowiekiem oznacza „być skierowanym na coś innego poza sobą”; żyć „w biegunowym polu napięć pomiędzy rzeczywistością a ideałami, które mają być zmaterializowane” (Frankl 2018, s. 71, 73). Zdaniem autora, „człowiek zawsze kieruje się oraz jest kierowany w stronę czegoś lub kogoś innego 
niż on sam - może to być zarówno oczekujący wypełnienia sens, jak i inny człowiek, którego spotykamy na swojej drodze. Im bardziej zapominamy o sobie - oddając się sprawie, której pragniemy służyć, bądź też osobie, którą pragniemy kochać - tym głębsze jest nasze człowieczeństwo i tym bardziej urzeczywistniamy swój potencjał" (Frankl 2011, s. 166). Jednostka doświadcza samotranscendencji w momencie, gdy realizując ważną dla siebie ideę czy wartość, jest do tego stopnia na niej skoncentrowana, że zapomina o sobie i swoich potrzebach. Osiągnięcie samotranscendencji pozwala człowiekowi ujrzeć świat z innej, ponadindywidualnej perspektywy. Wyzwala w nim chęć przekazania światu czegoś od siebie, tworzenia nowych wartości, podzielenia się swoimi zdolnościami, jak również bezinteresownego działania na rzecz innych. Człowiek odnajduje sens życia poza własną egzystencją, pochłaniające go sprawy zewnętrzne stają się istotą jego istnienia.

Samorealizacja oznacza ewolucję od, czyli przekraczanie granic podmiotu, celowe działanie transgresyjne jednostki. Natomiast samotranscendencja oznacza ewolucję do, czyli przekraczanie siebie ku światu i istniejącym w nim wartościom. Obie perspektywy tworzenia własnego ja, samorealizacja oraz samotranscendencja, ujmowane rozłącznie wydają się ze sobą sprzeczne. Gdy jednak, w myśl koncepcji edukacji integralnej Wiesława Andrukowicza (2001), obie drogi połączy się w kontinuum od-do, owa sprzeczność okazuje się pozorna. „Autokreacja od-do wyznacza zawsze punkt wyjścia od konkretnej egzystencji tu i teraz jako czystego aktu bycia tym oto i transgresyjnego wskazania realnej potencji bycia tym oto, a także wyznacza punkt dojścia do ogólnej istoty człowieczeństwa jako czystej potencji bycia i transcendentalnego wskazania idealnej potencji człowieka w ogóle" (Andrukowicz 2001, s. 201). Takie myślenie o autokreacji pozwala uwolnić się od redukcyjnego postrzegania jej jako samorealizacji albo samotranscendencji (Wąsiński 2018, s. 351) i dostrzec w niej trzecią drogę tworzenia własnego „ja”, w której ewolucja od i ewolucja do wzajemnie się warunkują.

Autokreację można zatem rozumieć jako całożyciowy, twórczy proces stawania się (w perspektywie własnej, innych i świata), na który składają się różnego rodzaju akty samorealizacyjne wiodące jednostkę do wewnętrznego rozwoju i samotranscendencji. „Jest to proces, który przy współudziale refleksji, samowiedzy, samoświadomości oraz osobowości dynamicznej, systemu wartości i czynników typu: wyobraźnia i ekspresja, na bazie doświadczeń ludzkich, złączonych z naturalnym potencjałem 
człowieka i jemu właściwą wrodzoną tendencją rozwojową, prowadzi jednostkę do odkrywania znaczeń i sensów świata, drugiego i siebie" (Górniok-Naglik 2018, s. 167).

Najkrócej rzecz ujmując, w ramach pierwszej drogi tworzenia własnego „ja” - samorealizacji - jednostka zyskuje samoświadomość, która pomaga jej określić siebie i swoje miejsce w świecie w kontekście zinternalizowanych wartości. Druga droga - samotranscendencja - ujawnia się w gotowości jednostki do wejścia ze swoim potencjałem w relacje ze światem zewnętrznym z intencją jego ulepszenia. Autokreacja, jako trzecia droga tworzenia siebie, łączy obie orientacje (ku sobie oraz ku światu) w kontinuum twórczego procesu stawania się człowieka.

\section{O związkach pasji z autokreacją w ujęciu samorealizacji}

Wspólnym mianownikiem dla pasji i autokreacji jest rozwój. Człowiek rozwija się wielowymiarowo. Na poziomie fizjologicznym, poprzez optymalizację swoich funkcji biologicznych, dąży do dobrego samopoczucia. $\mathrm{Na}$ poziomie społecznym, w drodze samorealizacji, zmierza ku uniezależnieniu się od świata. Na skutek rozwoju realizowanego na poziomie podmiotowym zaczyna rozumieć siebie, jak również odnajduje sens własnej egzystencji. Z kolei na poziomie rozwoju metafizycznego, autotranscendentnego, osiąga umiejętność przekraczania siebie, afirmuje życie, odczuwa jedność ze światem (Straś-Romanowska 1995, s. 44). Celem rozwoju, ogólnie rzecz biorąc, „jest uzyskanie możliwie pełnej harmonii ze światem”, jego efektem zaś „wytworzenie się pełnej otwartości na doświadczenia, ciągłej gotowości uwzględniania zmian, jakie się dokonują tak w samopoznaniu, jak i poznawaniu świata" (Gałdowa 1995, s. 158). Zdaniem Kazimierza Obuchowskiego, osoba ludzka rozwija się, bo potrafi stworzyć sobie i uzasadnić koncepcję stanów docelowych, do jakich dąży (Obuchowski 2004, s. 25). Za taką koncepcję z całą pewnością uznać można osobistą pasję człowieka, którą uzasadnia głębokie przekonanie podmiotu o sensowności i ważności podejmowanych w jej ramach czynów. Doświadczenia towarzyszące człowiekowi w chwili obcowania z obiektem pasji, działania, które podejmuje, wypełniają go energią, dodają sił, inspirują do dalszych poszukiwań i rozwoju (Litawa 2019). Podmiot wyznacza sobie cele w dziedzinie swoich zainteresowań, a następnie z dużą determinacją dąży do tego, by je zrealizować. W tej perspektywie pasję można postrzegać jako 
czynnik dynamizujący rozwój jednostki w różnych wymiarach jej egzystencji (od biologicznego po metafizyczny), a tym samym jako drogę autokreacji umożliwiającą jednostce ewolucję od siebie ku światu.

Tym, co bez wątpienia łączy pasję z autokreacją, są wartości. Wartości, ujmowane z perspektywy subiektywizmu aksjologicznego, nie istnieją same w sobie, ale powstają i trwają w obrębie pewnego złożonego układu. To człowiek powołuje je do istnienia, kreując, poprzez podejmowane przez siebie działania, sytuację aksjologiczną (Gołaszewska 1990, s. 32). Istotnym aspektem rzeczywistości, który stanowi podstawę dla zaistnienia sytuacji aksjologicznej, jest osobista pasja jednostki. Realizujący pasję podmiot samookreśla siebie w kontekście wartości, które uznaje za ważne, tworzy swoje ,ja” w myśl zgodnego z przyjętymi wartościami projektu wizji siebie. Warto zauważyć, że urzeczywistniając swoją pasję, jednostka nie dąży do wypełnienia jakiejś konkretnej, abstrakcyjnie ujętej wartości, ale wprowadza w świat pewne dobro, dąży do jakościowo dodatniej przemiany w świecie albo w sobie samym, zbliżając się w ten sposób do uznawanego ideału. Parafrazując słowa Marii Gołaszewskiej, człowiek posiadający pasję aspiruje ku wytworzeniu określonego przedmiotu albo stanu rzeczy z uwagi na pewien ideał. Dążąc do jego urzeczywistnienia, podejmuje pewne decyzje, wypełnia zaplanowane zadania - w ten sposób wprowadza wartości w świat (Gołaszewska 1990, s. 46). Pasja wyzwala aktywność zorientowaną na osiągnięcie tego, co z punktu widzenia danej osoby jest wartościowe, sposób zaś realizacji pasji i ostateczny efekt podjętych działań są czynnikami tworzącymi wartości. Realizowane w ramach pasji wartości, pełniąc rolę ukierunkowującą i sensotwórczą, wytyczają ścieżkę autokreacji podmiotu.

Kolejną wspólną dla pasji i autokreacji kategorią bez wątpienia jest twórczość. W perspektywie procesualnej twórczość może być rozpatrywana na dwa sposoby: jako proces twórczy i jako proces tworzenia przez człowieka samego siebie. Pierwszy zorientowany jest na kreowanie wartości kulturowych, drugi - wartości osobowych. Obydwa pozostają ze sobą w istotnej zależności. Każde bowiem twórcze działanie wywołuje w jednostce osobotwórcze efekty (Górniok-Naglik 2014, s. 118). W pełni urzeczywistniona twórczość daje człowiekowi obszar wolności, śmiałość w podejmowaniu wyzwań życia, mądrość płynącą z dokonań, świadomość granic własnych możliwości; umożliwia realizację danego potencjału (indywidualnego i kulturowego), jest źródłem radości istnienia, potwierdzeniem ważnych dla jednostki wartości (Góralski 2014, s. 364). 
Pasjonat jest twórcą, można rzec, podwójnym. Tworząc swoje „dzieło” (przedmiot, ideę czy stan rzeczy), tworzy zarazem samego siebie. Nie ulega bowiem wątpliwości, że wszystkie, nawet najdrobniejsze osiągnięcia wynikające $z$ realizacji pasji mogą nieść ze sobą walory poznawcze, praktyczne, estetyczne czy wychowawcze, co nie pozostaje bez znaczenia dla sfery osobowości jednostki. W zachodzącym w ramach pasji procesie twórczym człowiek powołuje do istnienia nowe byty, wydobywa z siebie jakąś ideę, konstruuje nową rzeczywistość. W ten sposób osiąga poczucie spełniania swej istotowości (Górniewicz 1995, s. 50). Realizacja pasji jest zadaniem twórczym, przy czym to właśnie z pasji podmiot czerpie siłę do tworzenia (również samego siebie).

W twórczość wpisane są działania transgresyjne. Zachodzące $\mathrm{w}$ ich ramach zmiany mają charakter intencjonalny i zorientowane są na przekraczanie dotychczasowych granic podmiotu. Zgodnie z koncepcją Józefa Kozieleckiego, człowiek dąży do tego, by wyjść poza to, czym jest i co posiada. Chodzi o pokonanie aktualnych granic, zarówno fizycznych, jak i poznawczych. Jedną z głównych sił uruchamiających działania transgresyjne jest dążenie do potwierdzania i wzrostu własnej ważności jako osoby (motywacja hubrystyczna), ale również zaspokojenie ciekawości, dążenie do poznania prawdy, wywoływanie pozytywnych emocji (motywacja poznawcza) (Kozielecki 1987, s. 211). Dla każdego pasjonata stawianie sobie wyzwań jest czymś naturalnym. Jednostka dąży do mistrzostwa, do stałego polepszania jakości swoich dokonań. Tym, co ją napędza, są intensywne przeżycia intelektualne, silne emocje oraz wysoki poziom zaangażowania wynikające z jej fascynacji, zachwytu i uwielbienia dla obiektu zainteresowań. Determinacja pasjonata do działania, tworzenia i tym samym przekraczania kolejnych granic jest niezwykle silna i, co ważne, ma charakter trwały - może się utrzymywać, tak jak pasja, nawet przez całe jego życie. Realizujący pasję podmiot wciąż dąży do samodoskonalenia, wypełniając tym samym zadanie autokreacji.

\section{Wnioski}

Z poczynionych w tekście analiz można wysnuć przynajmniej dwa wnioski. Po pierwsze, zarówno pasja, jak i autokreacja odnoszą się do rozwoju człowieka. W rozwój zaś wpisane są takie pojęcia jak twórczość, wartości, transgresja. I dla pasji, i dla autokreacji są to terminy kluczowe. Oso- 
ba z pasją wykazuje umiejętność twórczego przekształcania świata rzeczy, zjawisk, ale i własnej osobowości. Kreuje siebie zgodnie z przyjętymi wartościami, pokonując przy tym własne ograniczenia, przekraczając istniejący stan rzeczy. Wyszczególnione, wspólne kategorie dają podstawę do konstatacji, że pasja może stanowić jedną z dróg autokreacji.

Drugi wysnuty wniosek pozwala stwierdzić, że pasja może być czynnikiem wyzwalającym akt autokreacji. Zaangażowanie $\mathrm{w}$ realizację pasji ma charakter dynamiczny i wraz ze stopniem zaawansowania przechodzi na kolejne właściwe dla autokreacji etapy. Na początku człowiek poszukuje swojej drogi spełnienia. Gdy już ją znajdzie i uświadomi sobie swoje potrzeby, jak również odkryje swoje zdolności, zaczyna się w danym kierunku doskonalić: bada swoje możliwości, ustanawia cele do realizacji (Litawa 2019). Wspierając się na właściwych pasji wartościach, podejmuje trud tworzenia samego siebie, dąży do osiągnięcia mistrzostwa, co pozwala mu zbliżyć się do życzeniowej wizji własnego „ja”. W momencie, gdy na skutek podjętego i wypełnianego planu podmiot osiąga pożądany przez siebie status (w zależności od rodzaju pasji - sportowca, artysty itd.) i zyskuje uznanie dla samego siebie (podbudowane samorozumieniem i samoakceptacją), jego koncentracja na sobie i swoim rozwoju zaczyna stopniowo ustępować miejsca orientacji ku światu zewnętrznemu. Wiara we własne możliwości, poczucie przynależności, poczucie bycia wartościowym i autentycznym zyskane w toku samorealizacji przekładają się na zaistnienie u jednostki świadomości, że jej działania mogą mieć pozytywny wpływ na innych ludzi. Dobre samopoczucie, energia i poczucie wolności właściwe osobie posiadającej pasję (Halonen, Lomas 2014, s. 21-24) wzmacniają u niej poczucie sprawstwa i dodatkowo motywują ją do wejścia w interakcję ze światem zewnętrznym. Przed jednostką uchyla się furtka, za którą biegnie ścieżka ku samotranscendencji.

Przedstawione konkluzje wskazują na silny związek pasji z autokreacją. Pasja może dać początek autokreacyjnym dążeniom podmiotu; wyznaczać kierunek jego dalszego rozwoju; tworzyć płaszczyznę, na której jednostka może realizować swój osobisty projekt stawania się lepszą wersją siebie zarówno w sferze poznawczej, aksjologicznej, jak i egzystencjalnej. Dlatego też, w moim przekonaniu, proces urzeczywistniania harmonijnej pasji, w perspektywie samorealizacji jednostki, z całą pewnością można uznać za działanie autokreacyjne. 


\section{Zakończenie}

Problematyka osobistej, harmonijnej pasji oraz związanych z nią działań autokreacyjnych może stanowić interesujący i inspirujący obszar potencjalnych badań andragogicznych. To ważny aspekt ludzkiej egzystencji, u podłoża którego leży niepowtarzalna konfiguracja przeżyć i doświadczeń konkretnej jednostki. To również bardzo osobista sfera działalności człowieka, w której aż roi się od wątków budujących proces jego twórczego stawania się. Podjęcie jakościowych, pogłębionych analiz w tym kierunku może przyczynić się do pełniejszego zrozumienia złożoności procesu osobowego rozwoju człowieka w dorosłości. Niniejszy tekst można potraktować jako zaproszenie do podjęcia tego trudu.

\section{Bibliografia}

Csíkszentmihályi M. (1996), Przeptyw. Psychologia optymalnego doświadczenia, Studio Emka, Warszawa.

Czerepaniak-Walczak M. (2015), Pasja jako źródło i jako efekt emancypacji, [w:] M. Dudzikowa, M. Nowak (red.), O pasjach cudzych i własnych - profesorowie, KUL, Lublin, s. 53-68.

Dudzikowa M. (2015), O mojej miłości do ksiq̨żek. Esej osobisty, [w:] M. Dudzikowa, M. Nowak (red.), O pasjach cudzych i własnych - profesorowie, KUL, Lublin, s. 85-143.

Dudzikowa M., Nowak M. (2015), Wprowadzenie, [w:] M. Dudzikowa, M. Nowak (red.), O pasjach cudzych i własnych - profesorowie, KUL, Lublin, s. 7-12.

Frankl V. E. (2011), Człowiek w poszukiwaniu sensu, tłum. A. Wolnicka, Wydawnictwo Czarna Owca, Warszawa.

Frankl V. E. (1998), Homo Patiens. Logoterapia i jej kliniczne zastosowanie. Pluralizm nauk a jedność człowieka. Człowiek wolny, tłum. R. Czernecki, Z.J. Jaroszewski, Instytut Wydawniczy PAX,Warszawa.

Frankl V. E. (2018), Wola sensu. Założenia i zastosowanie logoterapii, tłum. A. Wolnicka, Wydawnictwo Czarna Owca, Warszawa.

Gałdowa A. (1995), Powszechność i wyjątek. Rozwój osobowości człowieka dorosłego, Wydawnictwo Księgarni Akademickiej, Kraków.

Gombrowicz W. (1986), Dziennik 1957-1961, Wydawnictwo Literackie, Kraków-Wrocław.

Górniewicz J. (2001), Kategorie pedagogiczne, Wydawnictwo UWM, Olsztyn.

Górniok-Naglik A. (2014), Edukacja kulturalna w liceum stymulatorem autokreacji młodzieży, Wydawnictwo Adam Marszałek, Torun. 
Halonen S. M., Lomas T. (2014), A passionate way of being: A qualitative study revealing the passion spiral, ,International Journal of Psychological Research”, no. 7(2), s. 17-28.

Litawa A. (2019), O uczeniu się inspirowanym pasją na przykładzie biografii edukacyjnej miłośnika sportu, „Edukacja Dorosłych”, nr 2(81), s. 63-75.

Matwijów B. (1994), Samokształtowaniesię człowieka w pedagogicznych koncepcjach XX wieku, Uniwersytet Jagielloński, Kraków.

Philippe F. L., Vallerand R. J., Lavigne G. (2009), Passion does make a difference in people's lives: A look at wellbeing in passionate and nonpassionate individuals, „Applied Psychology: Health and wellbeing”, no. 1(1), s. 3-22.

Popek S. L. (2015), O istocie i mechanizmach pasji, [w:] M. Dudzikowa, M. Nowak (red.), O pasjach cudzych i własnych - profesorowie, KUL, Lublin, s. 15-35.

Robinson K., Aronica L. (2012), Uchwycić żywioł. O tym, jak znalezienie pasji zmienia wszystko, tłum. A. Baj, Element, Kraków.

Stenseng F., Rise J., Kraft P. (2011), The dark side of leisure: obsessive passion and its covariates and outcomes, „Leisure Studies”, no. 30(1), s. 49-62.

Straś-Romanowska M. (1995), Implikacje dla teorii rozwoju osobowości pochodzace z założeń antropologii filozoficznej (Wprowadzenie do teorii osobowości człowieka dorosłego), [w:] J. Trempała (red.), Rozwijający się człowiek w zmieniajacym się świecie, WSP, Bydgoszcz, s. 37-49.

Vallerand R. J. (2012), The role of passion in sustainable psychological well-being, „Psychology of Well-Being: Theory, Research and Practice”, Vol.2, s. 2-21.

Wąsiński A. (2018), Autokreacja małżonków bezdzietnych do wielowymiarowego rodzicielstwa adopcyjnego, Wydawnictwo Uniwersytetu Łódzkiego, Łódź.

Wąsiński A. (2011), W poszukiwaniu sensu bycia rodzicem, czyli o duchowym zrodzeniu na drodze autokreacji do rodzicielstwa adopcyjnego, „Chowanna”, nr 1, s. 315-321.

Zgółkowa H. (red.) (2000), Praktyczny słownik współczesnej polszczyzny, t. 28, KURPISZ, Poznań. 